\title{
RECURRENT ADHESIONS OF THE LABIA MINORA IN GIRLS: NEW SOLUTIONS
}

\begin{abstract}
N.K. SILINA
PhD, senior researcher, Department of Medical and Psychosocial Health Problems of the Family, Institute of Pediatrics, Obstetrics and Gynecology of the NAMS of Ukraine

ORCID: 0000-0002-5456-8684
\end{abstract}

\section{M.Y. SERGIENKO}

PhD, associate professor, Obstetrics and Gynecology Department, Faculty of Postgraduate Education of the Donetsk National Medical University named after Maxim Gorky

ORCID: 0000-0001-6795-769X

\section{E.F. CHAYKIVSKA}

$\mathrm{PhD}$, assosiate professor of the Obstetrics, Gynecology and Perinatology Department of Postgraduate Education Faculty, Lviv National Medical University

ORCID: 0000-0001-5323-9611

\section{O.V. ZAYCHENKO}

Head of the Department of Pediatric Urogynecology, Institute of Pediatric Obstetrics and Gynecology of the NAMS of Ukraine

ORCID: 0000-0001-6860-1556

\section{T.M. SILINA}

MD, professor, Department of Family Medicine and Outpatient Care of the National Medical Academy of Postgraduate Education named after P.L. Shupyk

ORCID: 0000-0002-6552-1048

\section{I.V. BACHYNSKA}

Gynecologist of Pediatric and Adolescent Gynecology Department, National Children's Specialized Hospital "Okhmatdet"

ORCID: 0000-0002-6591-8213

\section{I.V. GAVRILOVA}

Head of the Pediatric and Adolescent Gynecology Department, National Children's Specialized Hospital "Okhmatdet"

\section{Contacts:}

Natalia K. Silina Institute of Pediatrics, Obstetrics and Gynecology of the NAMS of Ukraine, Department of medical and psycho-social problems of the family 04050, Kyiv, Manuilskogo, 8 tel.: +38 (063) 3052131 e-mail:dr.silina@gmail.com

\section{INTRODUCTION}

Reproductive potential is the ability of the girls to give birth to healthy offspring when she gets to childbearing age. The level and quality of reproductive potential is determined by the combined effect of the complex medical and social factors that form the index of women's health in the future readiness for sexual partnership and responsible motherhood. However, there is a worldwide trend of reduction of the number of healthy women in the general population [1-2]. There is an increase of gynecological diseases among adolescent girls such as inflammatory processes of pelvic organs, menstrual disorders, namely menorrhagia and dysmenorrhea, reaching almost $75 \%$ in the 15-18 age groups (according to epidemiological longitudinal study "Family and Children of Ukraine" (2008). The final formation of the reproductive system and physical health in adult women mostly depends on the comfortable and healthy duration of childhood and puberty. Therefore, the prevention of girls' health disorders is certainly an important contribution to the reproductive, intellectual, economic, political reserve of society. This issue is particularly acute in recent years, when a wide depopulation on the background of deterioration in the quality characteristics of the population (in the first place - general health) indicates that Ukraine entered a period of long-term demographic crisis.

One of the important factors worsening reproductive health of young women today is the chronic duration of inflammatory processes in childhood.

\section{ANALYSIS OF PUBLISHED DATA AND RESEARCH TASK}

In the structure of gynecological diseases of childhood leading place belongs to inflammatory processes of the external genitalia and recurrent conductive adhesive processes of vulva. Relapse of vulvar adhesions in girls aged 2-8 years according to official statistics is up to $11.6-14 \%$, but in real life the percentage of recurrence is much higher and get up to $40 \%$ in 3 of the month and $25 \%$ in 6 month after treatment, since not enough long-term observation of this group of patients is done [8].

The period of the girl childhood is characterized by low functional activity of the reproductive system: estradiol secretion is negligible, antral follicle maturation occur infrequently and irregularly, the secretion of gonadotropin-releasing hormone is impermanent; sub-systems receptor links are not developed, the secretion of neurotransmitters is poor. Age of 3-4 years is a period of natural decline of ovarian follicles at girls on $5-10 \%$, which predisposes development of hypoestrogenism. Histological study of the follicles of girls of prepubescent period made by Y.M. Meyer in 1979 has found that in age of 2-4 years only a few follicles get to the maturing stage [5].

However, the widespread belief that the main etiological factor in the pathological process of the vulva is an adhesive hypoestrogenic state isn't correct. According to studies conducted by a group of scientists, M.K. Caglar et al., estradiol levels in girls with and without adhesions of their presence was the same [3]. In one of the retrospective studies the successful use of estrogen ointment was reported only in $15 \%$ of cases [4].

The use of anti-inflammatory steroid agents such as cream Betamethasone 0.05\% twice a day for 4-6 weeks has been succeeded in the treatment of recurrent adhesions in girls' neutral periods in $68 \%$ of cases [5]. In addition, it is noted that recurrent adhesive process of the vulva in girls is accompanied by asymptomatic bacteriuria [6].

According to the Royal Melbourne Children's Hospital (Royal Children's Hospital Melbourne), manual separation of adhesions accompanied by high psychic traumatization of girls and subsequent high risk of recurrence, and also the use of creams containing estrogen, accompanied by a high risk of recurrence [7].

Maturing of the reproductive system in the age of 3-6 years is determined by certain peculiarities of endocrine and immune systems, ensuring the formation of locus minoris in the lower genital tract.

High frequency of adhesions in girls up to 8 years, not fully established the etiological factors in their development, as well as contradictory opinions about the diagnostic and therapeutic approaches to the management of girls with adhesive process of vulva determine the importance of this problem. Multicenter study of medical and social factors of recurrent adhesions showed that mothers of healthy girls possess a greater degree of knowledge about the menstrual function of the girls, the rules of personal hygiene and often implement them than mothers of girls with recurrent adhesions [8].

The aim of our research work was to research violation of the rules of intimate hygiene as one of the main factors leading to adhesive processes of the vulva, to find the true percentage of recur- 
rence of vulva adhesions and develop the concept of the prevention of this disease.

\section{MATERIAL AND METHODS}

The total number of patients was 290 mothers from Central (Kyiv), Western (Lviv), East (Donetsk) regions of Ukraine and their 290 daughters. The criteria for the inclusion of the study were 290 girls aged 2 to 8 years with recurrent adhesions of the labia minora ( 2 or more). Moms have signed an informed consent form. All mothers participating in the study were given the opportunity to answer questions in private and girls were examined in an atmosphere of complete comfort. Girls with proven allergic to chamomile have been excluded from the study.

Group I include 145 girls with recurrent adhesions of the labia minora, mothers who were consulted on the rules of personal hygiene and healthy way of life and got recommendations to use for intimate hygiene saugella poligyn 1 time per day continuously for 6 months after a standard course of topical therapy.

II group include 145 girls with recurrent adhesions of the labia minora, whose mothers used any product in the usual mode.

All girls had local treatment that was conducted for 10 days after adhesion separation: baths in a solution of medical herbs 1 times a day in the evening, application of sea buckthorn ointment in the morning and laevomecolum in the evening on vulva.

We evaluate the effectiveness of the results of a complex approach of recurrent adhesions, which included counseling mothers about the rules on intimate hygiene and healthy way of life and the use of saugella poligyn ("Rottapharm", Italy) for the prevention of recurrent adhesions of the labia minora at children. Saugella poligyn is a liquid soap for personal hygiene containing chamomile essential oil with anti-allergic and anti-inflammatory action.

The health status in both groups of patients was evaluated in 1, 3 and 6 months after local treatment. The percentage of recurrence of adhesions and inflammatory processes of the external genitalia was determined. The data of urogenital smear test and bacteriological test of vaginal secretions are obtained. Also a survey mothers about their level of knowledge about the basics of personal hygiene was done.

\section{THE RESULTS OF THE STUDY AND DISCUSSION}

According to the survey of 290 mothers it was found that adhesions occurred at girls with chronic vulvitis in $40.37 \%$ of cases. The greatest percentage of recurrence occurred within 3 months in $37.5 \%$ of girls, $25 \%$ in 6 months and in a year in less than $8 \%$ of the girls. Only $40 \%$ of mothers believe that underwear should be changed when dirty and only $25 \%$ use a separate towel for the genital organs, but an individual washcloth and soap in $95 \%$.

Most of women used their personal soap for girls. After defecation $80 \%$ of girls are used to pass hygienic washing away and only $60 \%$ of mothers change diapers every $2-3 \mathrm{hrs}$.

It was found that almost $82 \%$ of mothers believe that it is necessary to implement lessons for healthy life style in secondary schools and ready to listen a lecture on the rules of personal girls hygiene.

Before treatment, in group 1 there were girls with following clinical and laboratory characteristics (Table):

3yperemia of the mucous of the external genitalia in $88(60.68 \%)$;

3 95 (65.51\%) girls reported on persistent discomfort in the vulva;

pathological discharge from vagina had 88 (60.68\%) patients;

- Escherichia coli, Staphylococcus aureus, Klebsiella pneumonia and/or association of bacteria in clinically insignificant titer was found at 35 (24.13\%) girls and clinically significant titer at 34 (23.44\%) girls;

3 more than half of the girls had inflammatory smear test (60.68\%).

Patients at group 2 had the following clinical and laboratory characteristics prior to treatment (Table):

3 hyperemia of the mucous of the external genitalia in $86(59.31 \%)$;

- 97 (66 89\%) of the girls reported on the constant discomfort in the vulva;

3 pathological discharge from vagina had 86 (59.31\%) patients;

- Escherichia coli, Staphylococcus aureus, Klebsiella pneumonia and/or association of bacteria in clinically insignificant titer was found at 37 (25.51\%) girls and clinically significant titer at 35 (22.06\%) girls;

3 more than half of the girls had inflammatory smear test (59.31\%).

Thus the initial changes in the clinical and laboratory parameters for girls in group 1 and 2 were the same. None of complications were observed during the 10 days course of local therapy in the studied group.

One month after the treatment of patients in the first group showed a significant decrease of clinical manifestations of the inflammatory process in time (Figure 1). It was found that recurrence of inflammatory process of vulva happened in 3 months after treatment in 12 girls (8.27\%) and in 7 (4.82\%) patients in 6 months.

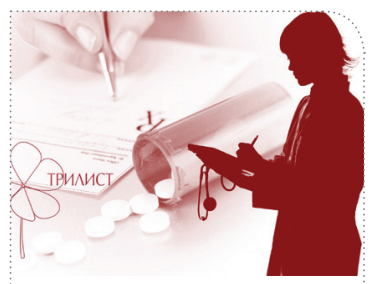

The study result showed that recurrent labial adhesions may be reduced by compliance of the rules of intimate hygiene and regular usage of product for personal hygiene 
TABLE. CLINICAL AND LABORATORY CHARACTERISTICS OF PATIENTS

\begin{tabular}{|c|c|c|c|c|c|c|c|c|}
\hline Parameters & \multicolumn{2}{|c|}{ Before treatment } & \multicolumn{2}{|c|}{ In one month after treatment } & \multicolumn{2}{|c|}{ In 3 month after treatment } & \multicolumn{2}{|c|}{ In 6 month after treatment } \\
\hline $\begin{array}{c}\text { Hyperemia of } \\
\text { external genitalia }\end{array}$ & $\begin{array}{c}88 \\
(60.68 \%)\end{array}$ & $\begin{array}{c}86 \\
(59.31 \%)\end{array}$ & $\begin{array}{c}5 \\
(3.44 \%)\end{array}$ & $\begin{array}{c}26 \\
(17.93 \%)\end{array}$ & $\begin{array}{c}12 \\
(8.27 \%)\end{array}$ & $\begin{array}{c}59 \\
(40.68 \%)\end{array}$ & $\begin{array}{c}7 \\
(4.82 \%)\end{array}$ & $\begin{array}{c}47 \\
(32.41 \%)\end{array}$ \\
\hline $\begin{array}{l}\text { Instant feeling } \\
\text { of discomfort of } \\
\text { external genitalia }\end{array}$ & $\begin{array}{c}95 \\
(65.51 \%)\end{array}$ & $\begin{array}{c}97 \\
(66.89 \%)\end{array}$ & $\begin{array}{c}5 \\
(3.44 \%)\end{array}$ & $\begin{array}{c}25 \\
(17.24 \%)\end{array}$ & $\begin{array}{c}12 \\
(8.27 \%)\end{array}$ & $\begin{array}{c}70 \\
(48.27 \%)\end{array}$ & $\begin{array}{c}7 \\
(4.82 \%)\end{array}$ & $\begin{array}{c}64 \\
(44.13 \%)\end{array}$ \\
\hline $\begin{array}{l}\text { Inflammatory } \\
\text { smear test }\end{array}$ & $\begin{array}{c}88 \\
(60.68 \%)\end{array}$ & $\begin{array}{c}86 \\
(59.31 \%)\end{array}$ & $\begin{array}{c}4 \\
(2.75 \%)\end{array}$ & $\begin{array}{c}23 \\
(15.86 \%)\end{array}$ & $\begin{array}{c}12 \\
(8.27 \%)\end{array}$ & $\begin{array}{c}59 \\
(40.68 \%)\end{array}$ & $\begin{array}{c}7 \\
(4.82 \%)\end{array}$ & $\begin{array}{c}47 \\
(32.41 \%)\end{array}$ \\
\hline $\begin{array}{l}\text { The result of } \\
\text { bacteriological } \\
\text { test }\end{array}$ & $\begin{array}{c}\text { Escherichia coli, } \\
\text { Staphylococcus } \\
\text { aureus, Klebsiella } \\
\text { pneumonia or } \\
\text { association of } \\
\text { bacteria } \\
\text { less than } 10^{3} \\
\text { in } 35(24.13 \%) \text {, } \\
\text { more than } 10^{3} \\
\text { in } 34(23.44 \%)\end{array}$ & $\begin{array}{l}\text { Escherichia coli, } \\
\text { Staphylococcus } \\
\text { aureus, Klebsiella } \\
\text { pneumonia or } \\
\text { association of } \\
\text { bacteria } \\
\text { less than } 10^{3} \\
\text { in } 37(25.51 \%) \text {, } \\
\text { more than } 10^{3} \\
\text { in } 35(22.06 \%)\end{array}$ & $\begin{array}{c}\text { Escherichia coli, } \\
\text { Staphylococcus } \\
\text { aureus, Klebsiella } \\
\text { pneumonia or } \\
\text { association of } \\
\text { bacteria } \\
\text { less than } 10^{3} \\
\text { in } 15(10.34 \%) \text {, } \\
\text { more than } 10^{3} \\
\text { in } 4(2.75 \%)\end{array}$ & $\begin{array}{c}\text { Escherichia coli, } \\
\text { Staphylococcus } \\
\text { aureus, Klebsiella } \\
\text { pneumonia or } \\
\text { association of } \\
\text { bacteria } \\
\text { less than } 10^{3} \\
\text { in } 22(15.17 \%) \text {, } \\
\text { more than } 10^{3} \\
\text { in } 15(10.34 \%)\end{array}$ & $\begin{array}{c}\text { Escherichia coli, } \\
\text { Staphylococcus } \\
\text { aureus, Klebsiella } \\
\text { pneumonia or } \\
\text { association of } \\
\text { bacteria } \\
\text { less than } 10^{3} \\
\text { in } 22(15.17 \%) \text {, } \\
\text { more than } 10^{3} \\
\text { in } 10(0.68 \%)\end{array}$ & $\begin{array}{l}\text { Escherichia coli, } \\
\text { Staphylococcus } \\
\text { aureus, Klebsiella } \\
\text { pneumonia or } \\
\text { association of } \\
\text { bacteria } \\
\text { less than } 10^{3} \\
\text { in } 22(15.17 \%) \text {, } \\
\text { more than } 10^{3} \\
\text { in } 41(28.27 \%)\end{array}$ & $\begin{array}{l}\text { Escherichia coli, } \\
\text { Staphylococcus } \\
\text { aureus, Klebsiella } \\
\text { pneumonia or } \\
\text { association of } \\
\text { bacteria } \\
\text { less than } 10^{3} \\
\text { in } 7(15.17 \%) \text {, } \\
\text { more than } 10^{3} \\
\text { in } 5(3.44 \%)\end{array}$ & $\begin{array}{c}\text { Escherichia coli, } \\
\text { Staphylococcus } \\
\text { aureus, Klebsiella } \\
\text { pneumonia or } \\
\text { association of } \\
\text { bacteria } \\
\text { less than } 10^{3} \\
\text { in } 34(15.17 \%) \text {, } \\
\text { more than } 10^{3} \\
\text { in } 27(23.44 \%)\end{array}$ \\
\hline
\end{tabular}

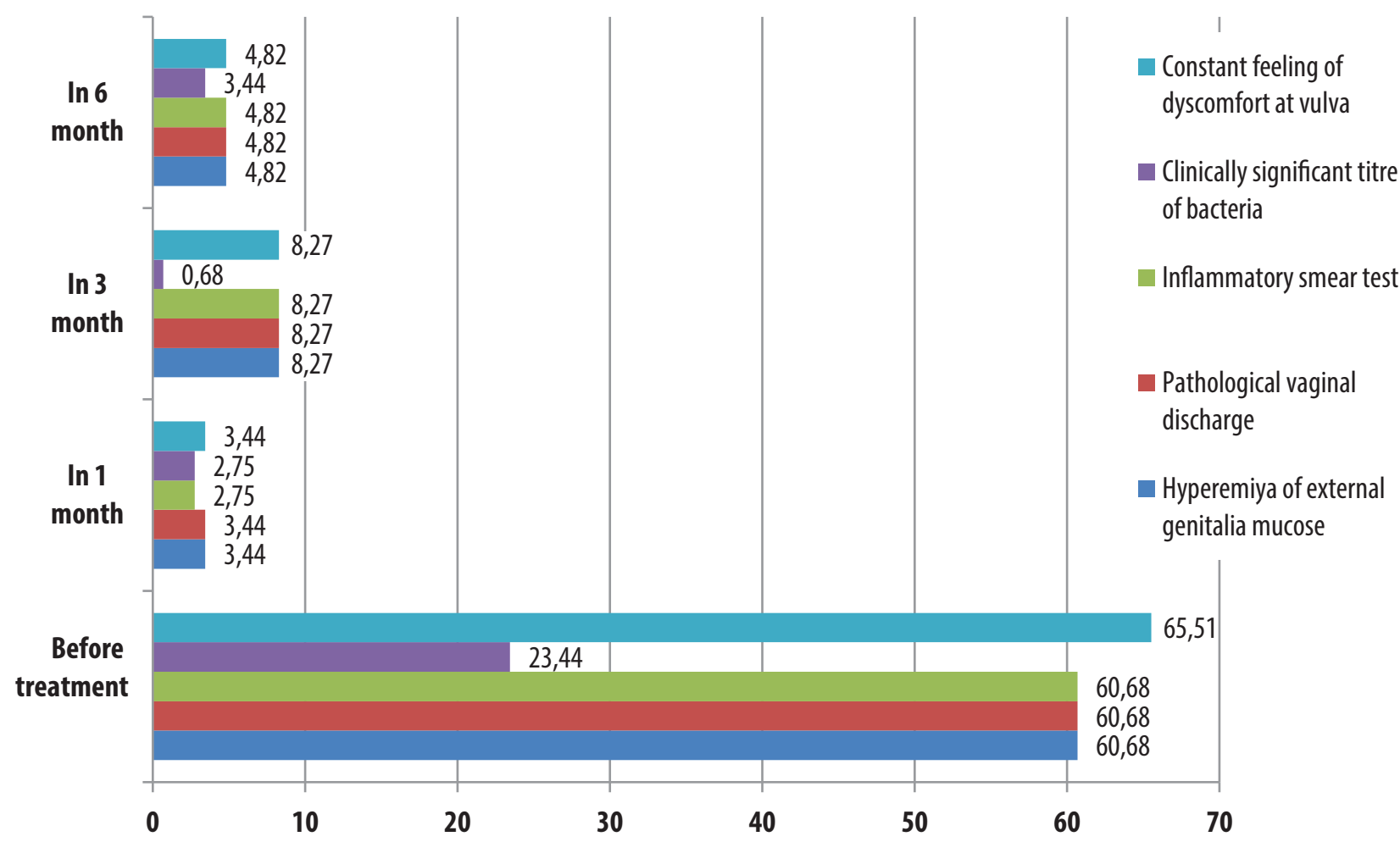

FIGURE 1. THE CHANGES OF CLINICAL AND LABORATORY CHARACTERISTICS IN PATIENTS OF GROUP 1 (\%)

As has been revealed that in both groups, the percentage of patients with constant discomfort in the vulva area is higher on of $10 \%$ than the percentage of girls with an inflammatory process that likely is evidence that at girls with recurrent adhesive process of vulva stable psychological discomfort in the vulva is formed.
There was a significant decrease in the number of patients with clinical signs of inflammation in group 2 in one month after the treatment (Figure 2). Hyperemia of the mucous of the external genitalia, abnormal leucorrhea and inflammatory type of smear was found at girls in 4 times less than before the treatment. Recurrence of the inflammatory process happened in 3 


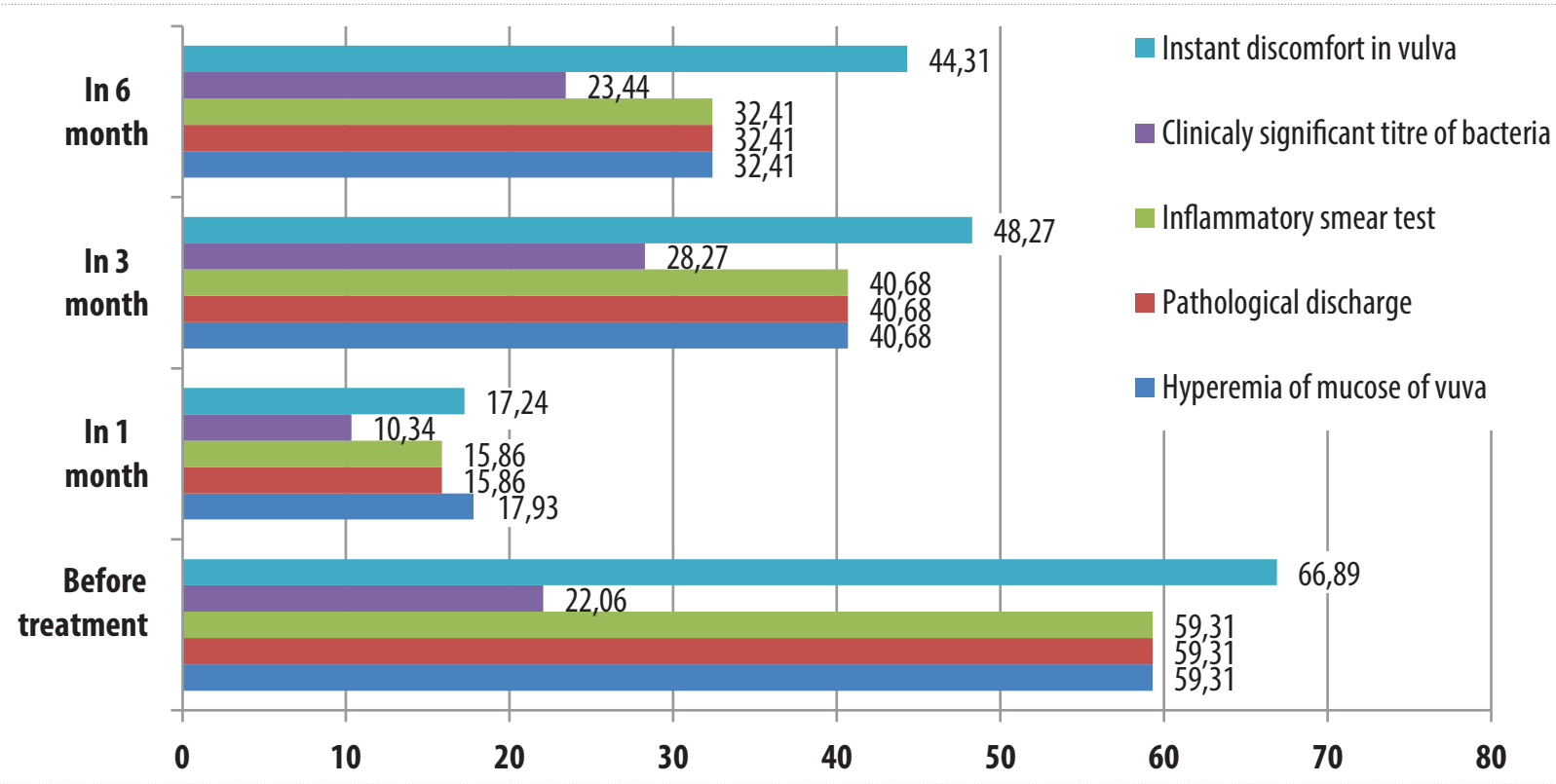

FIGURE 2. THE CHANGES OF CLINICAL AND LABORATORY CHARACTERISTICS IN PATIENTS OF GROUP 2 (\%)

months after treatment in $40.68 \%$ of cased and $32.41 \%$ after 6 months, exceeding the group 1 in several times (see Table). It was found that the incidence of recurrence of the vulva adhesive in the first group amounted to $3.44 \%$ in 3 months after treatment and $4.82 \%$ in 6 months. In the second group recurrence of adhesions occurred in $40.68 \%$ of patients in 3 months and in 6 months in $32.41 \%$ of cases (Figure 3).

\section{CONCLUSIONS}

1. The highest percentage of relapses occurred within 3 months after treatment - up to $41 \%$.

2. Active counseling of mothers of girls by general practitioner, pediatrician and adolescent gynecologist about the rules of personal hygiene in the different periods of girls' life could reduce the incidence of vulvar adhesions at girls of preschool age.

3. The great number of mothers need on information about healthy life style and intimate hygiene of girls was revealed in the study.

4. Recurrent labial adhesions may be reduced by compliance of the rules of intimate hygiene, and regular usage of optimal product of personal hygiene for example such as saugella poligyn ("Rottapharm", Italy).

5. The follow up of girl after treatment should be prolonged for at least for 1 year with regular check-ups (1 time in 3 months) with constant supervision of compliance of the intimate hygiene recommendations.

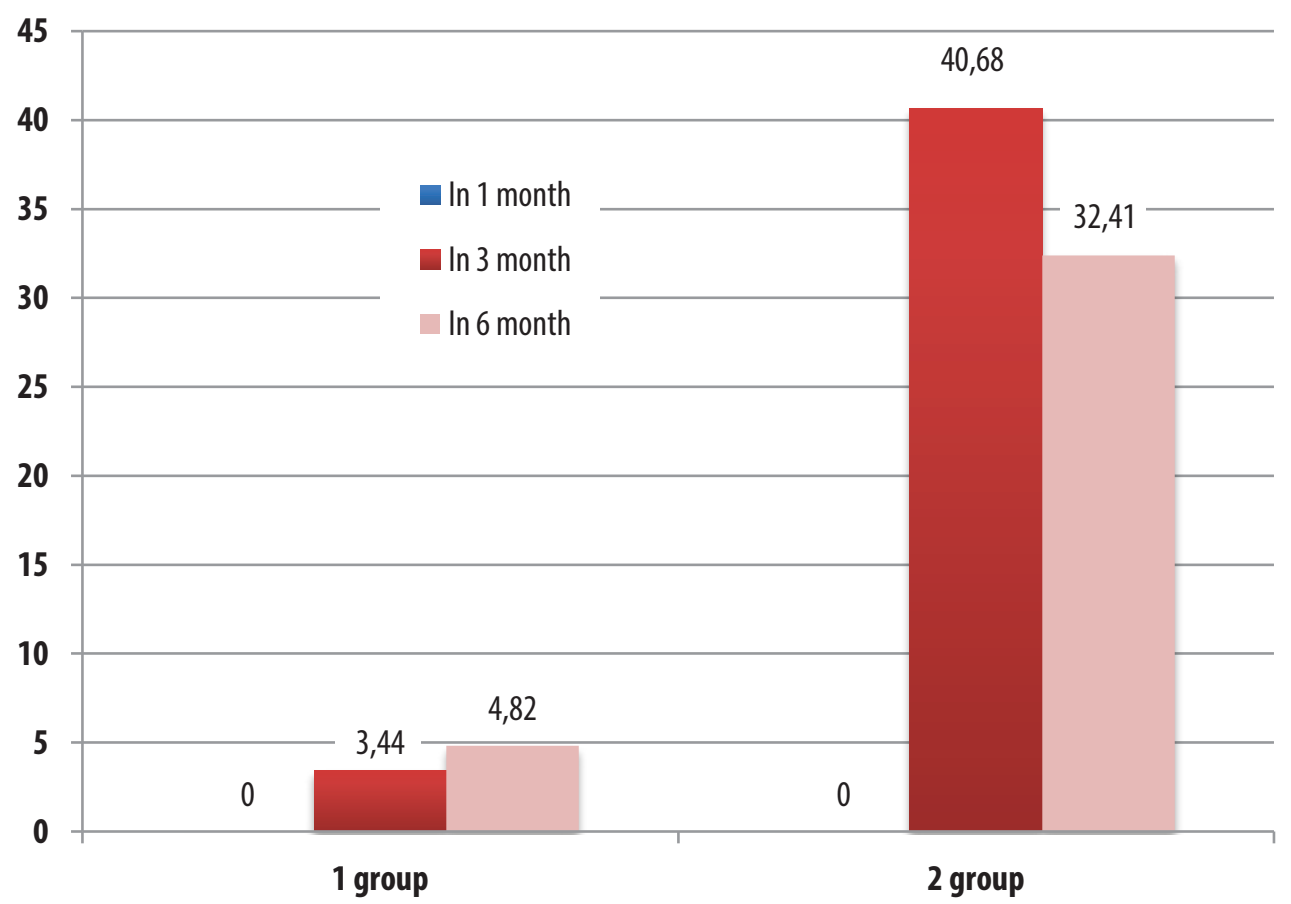

FIGURE 3. THE RECURENCE OF LABIAL ADHESIONS IN 1 AND 2 GROUP (\%) 


\section{REFERENCES/ЛITEPATУPA}

1. Радзинский, В.E.

Девушки-подростки РФ: современные тенденции формирования репродуктивного потенциала (обзор литературы) / В.Е. Радзинский, М.Б. Хамошина,

М.Г. Лебедева / Сибирский медицинский журнал. — 2010. — № 4 (25). — С. 9-14.

Radzinsky, V.E., Hamoshina, M.B., Lebedeva, M.G.

"Teenagers girls in Russian Federation: modern tendencies of formation of reproductive potential (review)." Siberian Medical Journal, 4(2010): 9-14.

2. Портнова, Н.И.

Состояние репродуктивного здоровья подростков - одна из задач диспансерного обследования / Н.И. Портнова, Е.В. Уварова //

Репродуктивное здоровье детей и подростков. - 2006. — № 2. - С. 10-15.

Portnova, N.I., Uvarova, E.V.

"Adolescent reproductive health is one of the tasks of the dispensary examination." Reproductive Health of Children and Adolescents, 2(2006): 10-15.

3. Caglar, M.K.

"Serum estradiol levels in infants with and without labial adhesions: the role of estrogen in the etiology and treatment." Pediatr Dermatol, 24(4) (2007): 373-375.

4. Eroglu, E., Yip, M., Oktar, T., Kayiran, S.M., Mocan, H.

"How should we treat prepubertal labial adhesions? Retrospective comparison of topical treatments: estrogen only, betamethasone only,

and combination estrogen and betamethasone." J Pediatr Adolesc Gynecol, 24(6) (2011): 389-391.

5. Myers, J.B., Sorensen, C.M., Wisner, B.P., Furness, P.D. 3rd, Passamaneck, M., Koyle, M.A.

"Betamethasone cream for the treatment of pre-pubertal labial adhesions." J Pediatr Adolesc Gynecol, 19(6) (2006): 407-411.

6. Leung, A.K., Robson, W.L.

"Labial fusion and asymptomatic bacteriuria." Eur J Pediatr, 152(3) (1993): 250-251.

7. Prepubescent Gynaecology. Clinical Practice Guidelines

[http://www.rch.org.au/clinicalguide/guideline_index/Prepubescent_Gynaecology/], last accessed Nov 19, 2015.

8. Antipkin, Y.G., Tatarchuk, T.F., Silina, N.K.

"Recurrent labial adhesions at girls: new aspects of an old problem." Reproductive Endocrinology, 5(19) (2014): 9-14.

\section{RECURRENT ADHESIONS OF THE LABIA MINORA IN GIRLS: NEW SOLUTIONS}

N.K. Silina, PhD, senior researcher, Department of Medical and Psychosocial Health Problems of the Family, Institute of Pediatrics, Obstetrics and Gynecology of the NAMS of Ukraine

M.Y. Sergienko, PhD, associate professor, Obstetrics and Gynecology Department, Faculty of Postgraduate Education of the Donetsk National Medical University named after Maxim Gorky

E.F. Chaykivska, PhD, assosiate professor of the Obstetrics, Gynecology and Perinatology of the Department of Postgraduate Education Faculty, Lviv National Medical University

0.v. Zaychenko, Head of the Department of Pediatric Urogynecology, Institute of Pediatrics, Obstetrics and Gynecology of the NAMS of Ukraine

T.M. Silina, MD, professor, Department of Family Medicine and Outpatient Care of the National Medical Academy of Postgraduate Education named after P.L. Shupyk

I.V. Bachynska, Gynecologist of Pediatric and Adolescent Gynecology Department, National Children's Specialized Hospital "Okhmatdet"

I.V. Gavrilova, Head of the Pediatric and Adolescent Gynecology Department, National Children's Specialized Hospital "Okhmatdet"

Relapse of vulvar adhesions in girls aged 2-8 years according to official statistics is up to $11.6-14 \%$, but in real life the percentage of recurrence is much higher and get up to $40 \%$ in 3 of the month and $25 \%$ in 6 month after treatment.

High frequency of adhesions in girls up to 8 years, not fully established the etiological factors in their development, as well as contradictory opinions about the diagnostic and therapeutic approaches to the management of girls with adhesive process of vulva determine the importance of this problem.

In the present study was evaluate the effectiveness of the complex treatment of recurrent adhesions of the labia minora at children, which included counseling mothers about the rules on intimate hygiene and healthy way of life and the use of a liquid soap saugella poligyn for the prevention of recurrent adhesions.

Group I include 145 girls with recurrent adhesions of the labia minora, mothers who were consulted on the rules of personal hygiene and got recommendations to use for intimate hygiene saugella poligyn for 6 months after a standard topical therapy. II group include 145 girls with recurrent adhesions of the labia minora, whose mothers used any product in the usual mode after a standard topical therapy.

It was found that the incidence of recurrence of the vulva adhesive in the first group amounted to $3.44 \%$ in 3 months after treatment and $4.82 \%$ in 6 months. In the second group recurrence of adhesions occurred in $40.68 \%$ of patients in 3 months and in 6 months in $32.41 \%$ of cases.

The study result showed that recurrent labial adhesions may be reduced by compliance of the rules of intimate hygiene and regular usage of product for personal hygiene such as saugella poligyn. The great number of mothers need on information about healthy life style and intimate hygiene of their girls.

The follow up of girl after treatment should be prolonged for at least for 1 year with regular check-ups (1 time in 3 months) with constant supervision of compliance of the intimate hygiene recommendations.

Keywords: labial adhesions, recurrent adhesions, teenage girls, saugella poligyn. 


\section{РЕЦИДИВУЮЧІ СИНЕХІЇ СТАТЕВИХ ГУБ У ДІВЧАТОК: НОВЕ ВИРІШЕННЯ ПРОБЛЕМИ}

Н.К. Сіліна, к. мед. н., старший науковий співробітник відділення медичних та психосоціальних проблем здоров'я сім'ї ІПАГ НАМН України

М.Ю. Сергієнко, к. мед. н., доцент кафедри акушерства, гінекології та перинатології факультета післядипломної освіти Донецького національного медичного університету ім. Максима Горького

Е.Ф. Чайківська, доцент кафедри акушерства, гінекології та перинатології факультета післядипломної освіти Львівського державного медичного університету ім. Данила Галицького

0.Н. Зайченко, завідувачка відділенням дитячої урогінекології ІПАГ НАмН України

Т.М. Сіліна, д. мед. н., професор кафедри сімейної медицини та амбулаторно-поліклінічної допомоги НмАПО ім. П.Л. Шупика

І.В. Бачинська, гінеколог відділення дитячої та підліткової гінекології Національної дитячої спеціалізованої лікарні «Охматдит»

І.В. Гаврилова, завідувачка відділенням дитячої та підліткової гінекології Національної дитячої спеціалізованої лікарні «Охматдит»

Рецидиви спайок статевих губ у дівчаток віком 2-8 років, за офіційною статистикою, складають до 11,6-14\%, однак у реальному житті їх частота $є$ вищою - до $40 \%$ через 3 місяці та 25\% через 6 місяців після лікування.

Висока частота синехій статевих губ у дівчаток до 8 років, не повністю встановлені етіологічні фактори їхньго розвитку, а також суперечні діагностичні і терапевтичні підходи до тактики ведення таких пацієнток визначають важливість даної проблеми.

У поданому дослідженні була вивчена ефективність комплексного лікування рецидивуючих синехій статевих губ у дівчаток, яке включало консультування матерів щодо правил інтимної гігієни і здорового способу життя та використання рідкого мила саугелла поліджин для профілактики рецидивів.

До групи І увійшло 145 дівчат із рецидивуючими синехіями статевих губ, матері яких були проконсультовані щодо правил особистої гігієни та отримали рекомендації використовувати для інтимної гігієни рідке мило саугелла поліджин упродовж 6 місяців після стандартного місцевого лікування. До групи II увійшли 145 дівчат із рецидивуючими синехіями статевих губ, які використовували будь-які засоби особистої гігієни після стандартної терапії.

Було встановлено, що частота рецидивів синехій статевих губ у першій групі склала 3,44\% через 3 місяці після лікування і 4,82\% через 6 місяців. У другій групі рецидиви спостерігалися в 40,68\% хворих через 3 місяці та в 32,41\% випадків через 6 місяців.

Результати дослідження показали, що частота рецидивів синехій статевих губ може бути зменшена шляхом дотримання правил інтимної гігієни і регулярного використання засобів особистої гігієни, таких як саугелла поліджин. При цьому значна кількість матерів потребує інформування щодо здорового способу життя та інтимної гігієни їхніх дочок.

Період спостереження за пацієнтками після лікування слід продовжити щонайменше на 1 рік із регулярним оглядом (1 раз на 3 місяці) і постійним контролем за дотриманням рекомендацій щодо інтимної гігієни.

Ключові слова: сінехії, рецидивуючі сінехії, дівчата-підлітки, саугелла поліджин.

\section{РЕЦИДИВИРУЮЩИЕ СИНЕХИИ ПОЛОВЫХ ГУБ У ДЕВОЧЕК: НОВЫЕ РЕШЕНИЯ ПРОБЛЕМЫ}

Н.К. Силина, к. мед. н., старший научный сотрудник отделения медицинских и психосоциальных проблем здоровья семьи ИПАГ НАМН Украины

М.Ю. Сергиенко, к. мед. н., доцент кафедры акушерства, гинекологии и перинатологии факультета последипломного образования Донецкого национального медицинского университета им. Максима Горького

э.Ф. Чайкивска, доцент кафедры акушерства, гинекологии и перинатологии факультета последипломного образования Львовского государственного медицинского университета им. Данила Галицкого

0.Н. Зайченко, заведующая отделением детской урогинекологии ИПАГ НАМН Украины

Т.М. Силина, д. мед. н., профессор кафедры семейной медицины и амбулаторно-поликлинической помощи НМАПО им. П.Л. Шупика

И.В. Бачинская, гинеколог отделения детской и подростковой гинекологии Национальной детской специализированной больницы «Охматдет»

И.В. Гаврилова, заведующая отделением детской и подростковой гинекологии Национальной детской специализированной больницы «Охматдет»

Рецидивы спаек половых губ у девочек в возрасте 2-8 лет, по официальной статистике, составляют до 11,6-14\%, но в реальной жизни их частота выше - до 40\% через 3 месяца и $25 \%$ через 6 месяцев после лечения.

Высокая частота синехий половых губ у девочек до 8 лет, не полностью установленные этиологические факторы их развития, а также противоречивые диагностические и терапевтические подходы к тактике ведения таких пациенток определяют важность данной проблемы.

В представленном исследовании была изучена эффективность комплексного лечения рецидивирующих синехий половых губ у девочек, которое включало консультирование матерей о правилах интимной гигиены и здорового образа жизни и использование жидкого мыла саугелла полиджин для профилактики рецидивов.

В группу I вошло 145 девушек с рецидивирующими синехиями половых губ, матери которых были проконсультированы о правилах личной гигиены и получили рекомендации использовать для интимной гигиены жидкое мыло саугелла полиджин в течение 6 месяцев после стандартного местного лечения. В группу II вошли 145 девушек с рецидивирующими синехиями половых губ, которые применяли любые средства личной гигиены после стандартной терапии.

Было установлено, что частота рецидивов синехий половых губ в первой группе составила 3,44\% через 3 месяца после лечения и 4,82\% через 6 месяцев. Во второй группе рецидивы наблюдались у 40,68\% больных через 3 месяца и в 32,41\% случаев через 6 месяцев.

Результаты исследования показали, что частота рецидивов синехий половых губ может быть уменьшена путем соблюдения правил интимной гигиены и регулярного использования средств личной гигиены, таких как саугелла полиджин. При этом значительное количество матерей нуждаются в информировании о здоровом образе жизни и интимной гигиены их дочерей.

Период наблюдения за пациентками после лечения следует продлить как минимум на 1 год с регулярным осмотром (1 раз в 3 месяца) и постоянным контролем за соблюдением рекомендаций относительно интимной гигиены.

Ключевые слова: синехии, рецидивирующие синехии, девочки-подростки, саугелла полиджин. 